\title{
MORPHOMETRIC ANALYSIS OF VRISHABHAVATHI WATERSHED USING REMOTE SENSING AND GIS
}

\author{
P T Aravinda ${ }^{1}$, H B Balakrishna ${ }^{2}$ \\ ${ }^{1}$ Assistant Professor, Department of Civil Engg, Govt Engg College Ramanagara, Karnataka, India, \\ aravindapt@gmail.com \\ ${ }^{2}$ Professor, Department of Civil Engg, Bangalore Institute of Technology, Karnataka, India, balubit@gmail.com
}

\begin{abstract}
Vrishabhavathi Watershed is a constituent of the Arkavathi River Basin, Bangalore Urban and Ramanagara District and covers an area of $381.465 \mathrm{Km}^{2}$, representing seasonally dry tropical climate. To achieve the Morphometric analysis, Survey of India (SOI) topomaps in 1:50000 scales are procured and the boundary line is extracted by joining the ridge points. This will serve as study area or area of interest for preparing base map and thematic maps. The recent changes are updated with the help of Remote sensing satellite data. The drainage map is prepared with the help of Geographical Information System tool and morphometric parameters such as linear, aerial and relief aspects of the watershed have been determined. These dimensionless and dimensional parametric values are interpreted to understand the watershed characteristics. From the drainage map of the study area dendritic drainage pattern is identified. Strahler (1964) stream ordering method is used for stream ordering of the watershed. The drainage density of the watershed is $1.697 \mathrm{~km} / \mathrm{km}^{2}$.
\end{abstract}

Index Terms: Morphometric analysis, Remote Sensing, GIS, SOI Topomap and Vrishabhavathi Watershed

\section{INTRODUCTION}

Water is known as the liquid for sustenance of life. All living beings are depending on water, without which no life exists on the earth. Earth has plentiful water due to the presence of Hydrological cycle on it, but most of it is unfit for living beings use and consumption. The study of the watershed morphometric analysis provides the beneficial parameters for the assessment of the ground water potential zones, identification of sites for water harvesting structures, water resource management, runoff and geographic characteristics of the drainage system. Morphometry is the measurement and mathematical analysis of the configuration of the earth's surface, shape, dimension of its landforms (Clarke, 1966). The Morphometric analysis consists of linear, Aerial and relief aspects.

For the present study Remote Sensing (Lillisand Thomas, 2002) and Geographical Information System (GIS) will be used as tools for managing and analyzing the spatially distributed informations. Arc GIS and QGIS are powerful softwares to analyze, visualize, update the geographical information, and create quality presentations that brings the power of interactive mapping and analysis. Many researchers have done morphometric analysis using Remote Sensing and GIS technique. (Shakil Ahmad et al., 2012) has used Geoinformatics for assessing the morphometric control on hydrological response at watershed scale in the upper Indus Basin. (Sangita Mishra et al., 2010) has presented a case study of Morphometric analysis and Watershed prioritization of Tel river using Remote sensing and GIS technique. (Vandana M, 2012) carried out morphometric analysis for Kabini River basin and morphometric analysis is used as a tool for prioritization of sub watershed in the basin. (Magesh N S, 2013) used Geoinformatics for extraction of river basin and carried out morphometric analysis for that extracted river basin. (Balakrishna $\mathrm{H} \mathrm{B}$, 2008) carried out morphometric analysis for Tippagondanahalli River basin for prioritization of sub watersheds.

\section{STUDY AREA}

Vrishabhavathi Watershed is a constituent of Arkavathi River Basin, Bangalore Urban and Ramanagara District and covers an area of $381.465 \mathrm{Km}^{2}$ lying between latitudes $12^{0}$ $44^{1} 37^{11}$ to $13^{0} 2^{1} 31^{11} \mathrm{~N}$ and longitudes $77^{0} 23^{1} 14^{11}$ to $77^{0}$ 
$34^{1} 59^{11}$ E. Vrishabhavathi River is originated from Peenya industrial area with an altitude of $930.250 \mathrm{~m}$ above mean sea level. As per the data normal annual rainfall received by the study area is $831 \mathrm{~mm}$. The geology of the study area is characterized by the granite gneiss. Fig 1 shows the Location Map of the Study area.

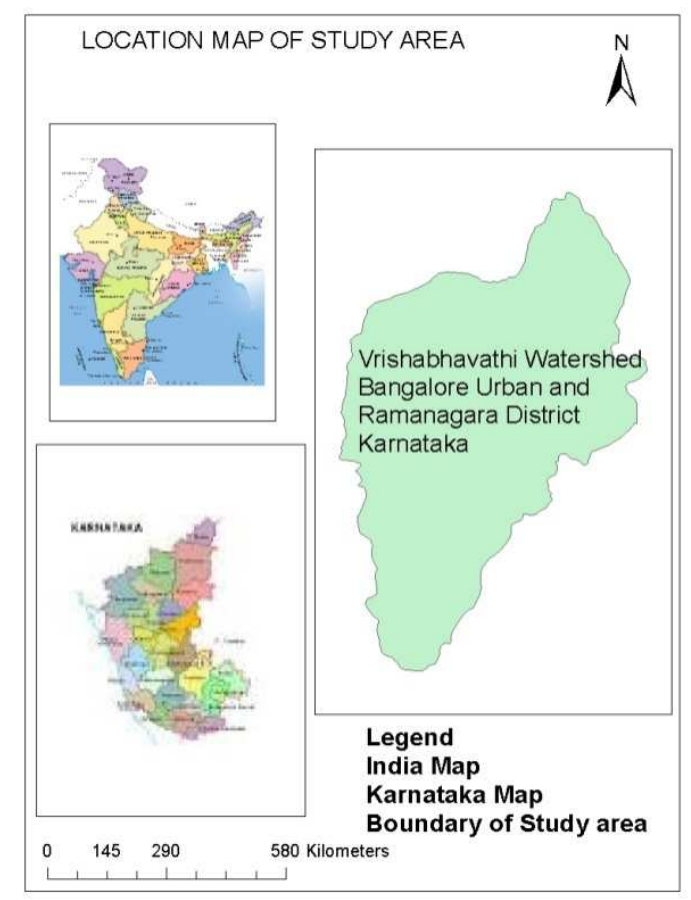

Fig-1: Location Map of Study area

\section{METHODOLOGY}

For the study outlet is taken at Vrishabhavathi Reservoir situated at Byramangala village of Ramanagara Taluk, Ramanagara District. The Fringe point is observed at hillock of Peenya industrial area. A common task in hydrology is to delineate a watershed from a topographic map. To trace the boundary, one should start at the outlet Vrishabhavathi Reservoir and then draw a line away on the left bank, maintaining it always at right angles to the contour lines. (The line should not cross the drainage paths) Continue the line until it is generally above the headwaters of the stream network. Return to the outlet and repeat the procedure with a line away from the right bank. The two lines should join to produce the full watershed boundary. The Digital Elevation Model (DEM) of the study area is generated using ArcGIS software. This helps in drawing the exact boundary line of the study area. The base map is prepared using SOI toposheet number $57 \mathrm{H} / 5,57 \mathrm{H} / 6,57 \mathrm{H} / 9$ and $57 \mathrm{G} / 12$ on $1: 50,000$ scale. The Topomaps are scanned and projected for delineating the required features. The Digitized maps are updated with the help of satellite imagery using QGIS and ArcGIS softwares. It consists of various features like the road network, settlements, water bodies, Vrishabhavathi River, canals etc. The South Western railway line passes through the study area from Mysore to Bangalore is delineated from the toposheet. The Bangalore-Mysore Highway and TavarekereKonanakunte road networks are delineated from the toposheet for the study area. The major settlements in the present study area such as Kengeri railway station and Hejjala Railway station are also delineated from the toposheet. The information content of this map is used as a baseline data to finalize the physical features of other thematic maps. Since the topo sheets are very old all the features like roads, railways, settlements etc are updated with the help of recent rectified and scaled satellite imageries of the area. Fig.2 shows Base map of Vrishabhavathi Watershed.

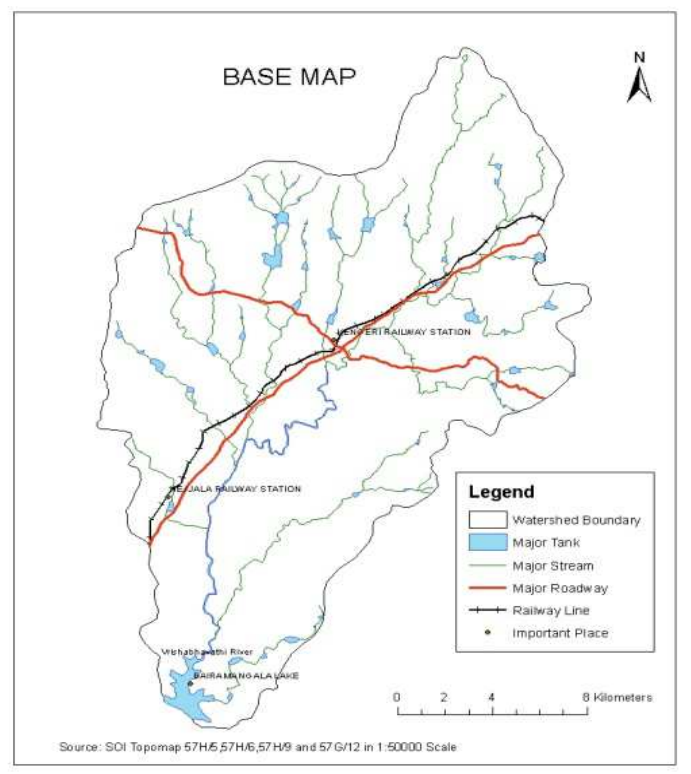

Fig-2: Base map of Vrishabhavathi Watershed

The drainage map prepared from the toposheet forms the base map for the preparation of thematic maps related to surface and groundwater. All the streams, Vrishabhavathi River, 
tributaries and small stream channels shown on the toposheet are extracted to prepare the drainage map.

The study area is a first, second, third, fourth, fifth and sixth order streams and Vrishabhavathi River are present. The present study area dendrite drainage patron is present. The flowing of water is tamed through construction of number of tanks and channels. Fig-3 shows Drainage map of Vrishabhavathi Watershed.

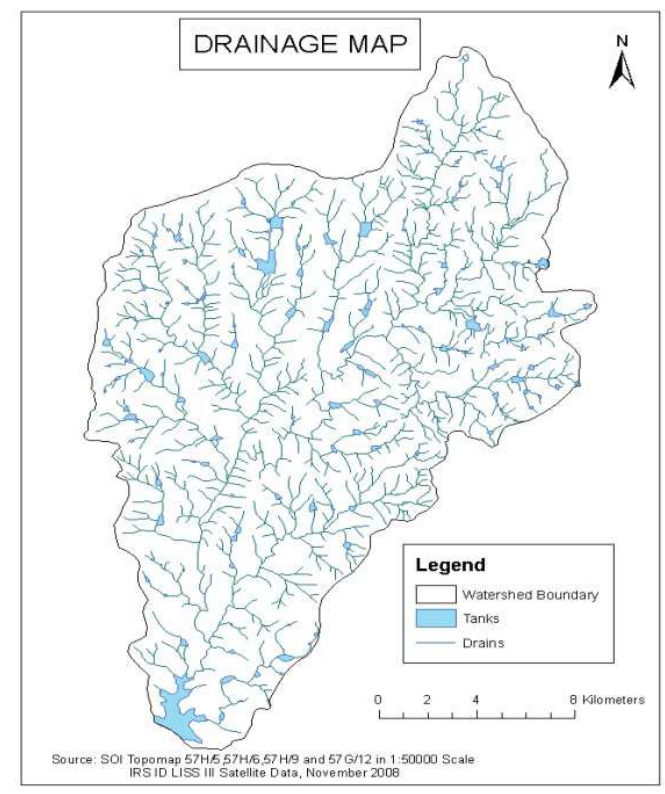

Fig-3: Drainage map of the Vrishabhavathi Watershed

\section{MORPHOMETRIC ANALYSIS}

Morphometric analysis, which is all about exploring the mathematical relationships between various stream attributes, used to compare streams and to identify factors that may be causing differences. The term Morphometry is derived from a Greek word, where "morpho" means earth and "metry" means measurement, so together it is measurement of earth features. This is an important factor for planning any watershed development.

Morphometric analysis also provides description of physical characteristics of the watershed which are useful for environmental studies, such as in the areas of land use planning, terrain elevation, soil conservation and soil erosion.

Morphometric analysis for the present study is grouped into three classes such as linear aspects, areal aspects and relief aspects.

\subsection{Linear Aspects}

Linear aspects include the measurements of linear features of drainage such as stream order, bifurcation ratio, stream length, stream length ratio, length of overland flow etc. The linear characteristics of the drainage basin are discussed below. (Ven Tee Chow, 1964)

\subsubsection{Stream orders}

The first step in drainage basin analysis is disignation of stream osders, following a system introduced into the United States by Horton (1956) and slightly modified by Strahler(1964). Assuming that one has available drainage network map including all intermittent and permanenet flow lines located in clearly defined valleys, the smallest fingertip tributaries are designated oreder 1. (Fig 4). Where two first oredr channels join, a channel segment of oredr 2 is found.

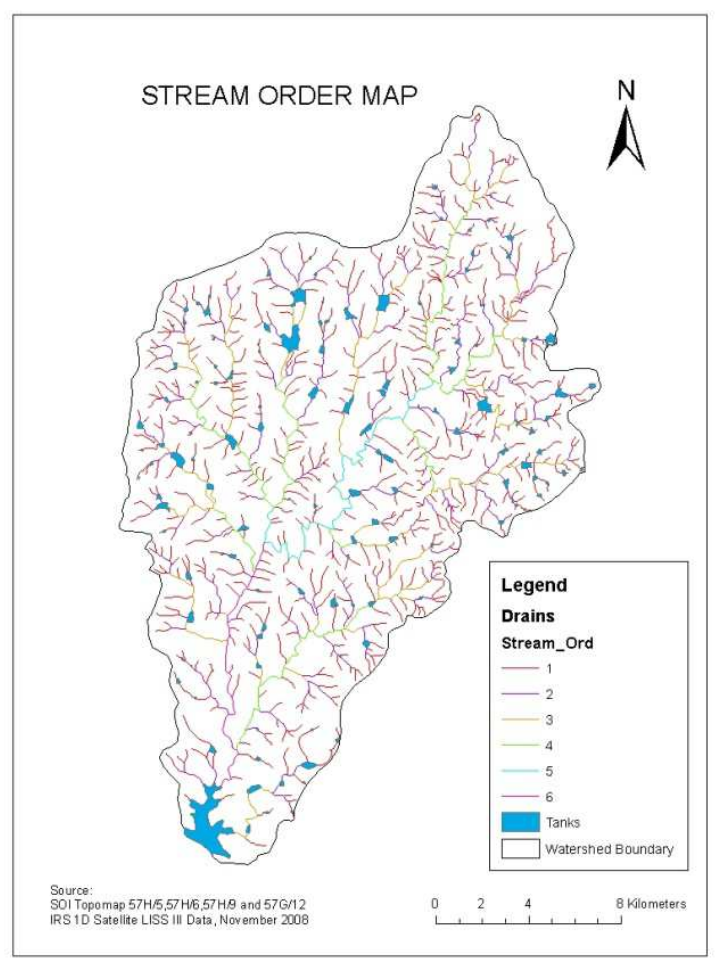

Fig-4: Stream order Map of Vrishabhavathi Watershed 
Where two of order 2 joins, segment of order 3 is formed; and so forth. The trunk stream through which all discharge of water and sediment passes is therefore the stream segment of highest order. Usefulness of the stream order system depends on the premise that, on the average, if a sufficiently large sample is treated, order number is directly proportional to size of the contributing watershed, to channel dimensions and to stream discharge at that place in the system. Because order number is dimensionless, two drainage networks differing greatly in linear scale can be compared with respect to corresponding points in their geometry through use of order number. After the drainage network elements have been assigned their order numbers, the segments of each order are counted to yield the number $N_{u}$ of segments of the given order $u$.

\subsubsection{Bifurcation Ratio}

It is obvious that the number of stream segments of any given order will be fewer than for the next lower order but more numerous than for the next higher order. The ratio of number of segments of a given order $N u$ to the number of segments of the higher order $\mathrm{N}_{\mathrm{u}+1}$ is termed the bifurcation ratio $R_{b}$ :

$$
\mathrm{R}_{\mathrm{b}}=\frac{\mathrm{N}_{\mathrm{u}}}{\mathrm{N}_{\mathrm{u}+1}}
$$

The bifurcation ratio will not be precisely the same from one order to the next, because of chance variations in watershed geometry, but will tend to be a constant throughout the series. Bifurcation ratio characteristically ranges between 3 and 5 for watersheds in which the geologic structures do not distort the drainage pattern. The theoretical minimum possible value of 2 is rarely approached under natural conditions. Because the bifurcation ratio is a dimensionless parameter, and because drainage systems in homogeneous materials tend to display geometrical similarity, it is not surprising that the ratio shows only a small variation from region to region. Abnormally high bifurcation ratios might be expected in regions of steeply dipping rock strata where narrow strike valleys are confined between hogback ridges. Average bifurcation ratio is calculated for the watershed as 3.84 (Table-1). Plotting the number of stream segments for each stream order on logarithmic scale and stream order on X-axis (Fig-4) reveals a good relationship between them.

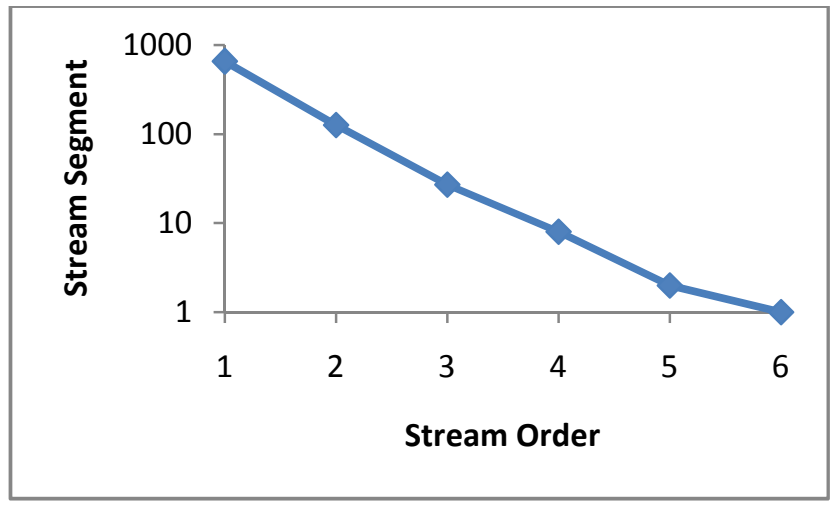

Fig-4: Regression of Stream order on Number of stream segments

\subsubsection{Stream Lengths}

Mean stream length $\bar{L}_{u}$ of a stream channel segment of order $\mathrm{u}$ is a dimensional property revealing the characteristic size of components of a drainage network and its contributing basin surfaces. Channel length is measured with the help of ArcGIS and QGIS softwares directly from the Stream Order map. To obtain the mean stream length of channel $\overline{\mathrm{L}}_{\mathrm{u}}$ of order $u$, the total length is divided by the number of stream segments $N_{u}$ of that order, thus:

$$
\overline{\mathrm{L}}_{\mathrm{u}}=\frac{\sum_{\mathrm{i}=1}^{\mathrm{N}} \mathrm{L}_{\mathrm{u}}}{\mathrm{N}_{\mathrm{u}}}
$$

Generally, The $\overline{\mathrm{L}}_{\mathbf{u}}$ increases with increase of order number. It can be seen from Table 1, that the mean length of channel segments of a given order is more than that of the next higher order. The total number of all stream segments $N_{u}$ in a stream order, total stream length $\mathrm{L}_{\mathrm{u}}$ in stream order $\mathrm{u}$, mean stream length for the watershed are calculated and is shown in Table-2. Fig-5 shows that there is linear relationship between mean stream length and stream order.

\section{Steam length ratio}

Stream length ratio $\left(\mathrm{R}_{\mathrm{L}}\right)$ is defined as the average length of stream of any order to the average length of streams of the next lower order and it is expressed as;

$$
R_{L}=\frac{\bar{L}_{u}}{L_{u-1}}
$$


Horton postulated that, the length ratio tends to be constant throughout the successive orders of the stream.

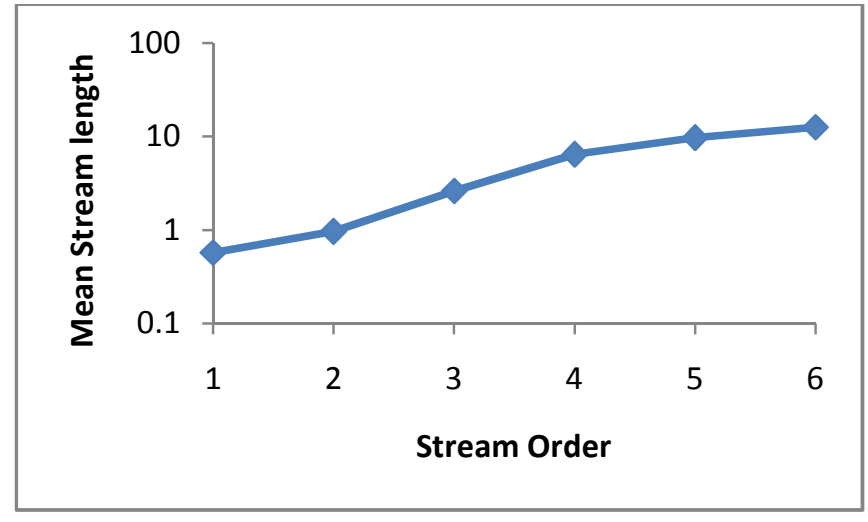

Fig. 5 Regression of stream order on mean stream length

\subsubsection{Length of overland flow}

Horton defined length of overland flow $\mathrm{L}_{0}$ as the length of flow path, projected to the horizontal, nonchannel flow from a point on the drainage divide to a point on the adjacent stream channel. He noted that length of overland flow is one of the most important independent variables affecting both the hydrologic and physiographic development of drainage basins. During the evolution of the drainage system, $\mathrm{L}_{0}$ is adjusted to a magnitude appropriate to the scale of the first order drainage basins and is approximately equal to one half the reciprocal of the drainage density. The shorter the length of overland flow, the quicker the surface runoff from the streams. For a present study Length of Overland Flow is 0.295 .

\subsubsection{Drainage pattern}

In geomorphology, a drainage system is the pattern formed by the streams, rivers, and lakes in a particular drainage basin. They are governed by the topography of the land, whether a particular region is dominated by hard or soft rocks, and the gradient of the land. Geomorphologists and hydrologists often view streams as being part of drainage basins. A drainage basin is the topographic region from which a stream receives runoff, through flow, and groundwater flow. Drainage basins are divided from each other by topographic barriers called a watershed. A watershed represents all of the stream tributaries that flow to some location along the stream channel. The number, size, and shape of the drainage basins found in an area varies and the larger the topographic map, the more information on the drainage basin is available. A drainage system is described as accordant if its pattern correlates to the structure and relief of the landscape over which it flows. Following are the some of the drainage patterns in the world.

Dendritic drainage pattern: Dendritic drainage systems are the most common form of drainage system. In a dendritic system, there are many contributing streams (analogous to the twigs of a tree), which are then joined together into the tributaries of the main river (the branches and the trunk of the tree, respectively). They develop where the river channel follows the slope of the terrain. Dendritic systems form in V-shaped valleys; as a result, the rock types must be impervious and non-porous.

Parallel drainage pattern: A parallel drainage system is a pattern of rivers caused by steep slopes with some relief. Because of the steep slopes, the streams are swift and straight, with very few tributaries, and all flow in the same direction. This system forms on uniformly sloping surfaces, for example, rivers flowing southeast from the Aberdare Mountains in Kenya. Parallel drainage patterns form where there is a pronounced slope to the surface. A parallel pattern also develops in regions of parallel, elongate landforms like outcropping resistant rock bands.

Trellis drainage pattern: The geometry of a trellis drainage system is similar to that of a common garden trellis used to grow vines. As the river flows along a strike valley, smaller tributaries feed into it from the steep slopes on the sides of mountains. These tributaries enter the main river at approximately 90 degree angles, causing a trellis-like appearance of the drainage system. Trellis drainage is characteristic of folded mountains, such as the Appalachian Mountains in North America.

Rectangular drainage pattern: Rectangular drainage develops on rocks that are of approximately uniform resistance to erosion, but which have two directions of jointing at approximately right angles. The joints are usually less resistant to erosion than the bulk rock so erosion 
tends to preferentially open the joints and streams eventually develop along the joints. The result is a stream system in which streams consist mainly of straight line segments with right angle bends and tributaries join larger streams at right angles.

Radial drainage pattern: In a radial drainage system, the streams radiate outwards from a central high point. Volcanoes usually display excellent radial drainage. Other geological features on which radial drainage commonly develops are domes and laccoliths. On these features the drainage may exhibit a combination of radial patterns. (Subramanya K, 2012)

The drainage pattern for the present study area is dendritic. The drainage pattern shows well integrated pattern formed by a main stream with its tributaries branching and rebranching freely in all direction. The dendritic pattern of drainage indicates that the soil is semi pervious in nature.

Table 1 Linear morphometric parameters of Vrishabhavathi watershed

\begin{tabular}{|l|c|l|l|l|l|}
\hline $\begin{array}{l}\text { Str } \\
\text { Ord }\end{array}$ & $\begin{array}{l}\text { No of } \\
\text { Segme } \\
\text { nts }\end{array}$ & $\begin{array}{l}\text { Total } \\
\text { length }\end{array}$ & $\begin{array}{l}\text { Bifurcation } \\
\text { Ratio }\end{array}$ & $\begin{array}{l}\text { Mean } \\
\text { length }\end{array}$ & $\begin{array}{l}\text { Length } \\
\text { Ratio }\end{array}$ \\
\hline 1 & 651 & 372.603 & & 0.572 & \\
\hline 2 & 126 & 121.225 & 5.166 & 0.962 & 1.681 \\
\hline 3 & 27 & 70.629 & 4.666 & 2.616 & 2.719 \\
\hline 4 & 8 & 51.272 & 3.375 & 6.409 & 2.449 \\
\hline 5 & 2 & 19.307 & 4.000 & 9.654 & 1.506 \\
\hline 6 & 1 & 12.537 & 2.000 & 12.537 & 1.298 \\
\hline
\end{tabular}

\subsection{Areal aspects}

Areal aspects $\left(A_{u}\right)$ of a watershed of given order $u$ is defined as the total area projected upon a horizontal plane contributing overland flow to the channel segment of the given order and includes all tributaries of lower order. The watershed shape has a significant effect on stream discharge characteristics, for example, the elongated watershed having a high bifurcation ratio can be expected to have alternated flood discharge. But on the other hand, the round or circular watershed with a low bifurcation ratio may have a sharp peak flood discharge.

The shape of a watershed has a profound influence on the runoff and sediment transport process. The shape of the catchment also governs the rate at which water enters the stream. The quantitative expression of watershed can be characterised as form factor, circularity ratio, and elongation ratio.

\subsubsection{Form factor}

Horton defines the form factor $\mathrm{R}_{\mathrm{f}}$ as a dimensionless ratio of watershed area (A) to the square of the length of the watershed (L). The value of form factor would always be less than 0.7854 (for a perfect circular watershed). The watershed with higher form factor are normally circular and have high peak flows for shorter duration, whereas elongated watershed with lower values of form factor have low peak flows for longer duration. For the present study area form factor is 0.327 .

$$
\mathrm{R}_{\mathrm{f}}=\frac{\mathrm{A}}{\mathrm{L}^{2}}
$$

Where $R_{\mathrm{f}}$ is the form factor, $L$ is the total length of watershed and $A$ is the total area of watershed.

\subsubsection{Circularity ratio}

Circularity ratio is the ratio between the area of watershed to the area of circle having the same circumference as the perimeter of the watershed (Miller, 1953). The value ranges from 0.2 to 0.8 , greater the value more is the circularity ratio. It is the significant ratio which indicates the stage of dissection in the study region. Its low, medium and high values are correlated with youth, mature and old stage of the cycle of the tributary watershed of the region, and the value obtained. For the present study area circularity ratio is obtained as 0.492 .

$$
\mathrm{R}_{\mathrm{c}}=\frac{4 \pi \mathrm{A}}{\mathrm{P}^{2}}
$$

Where $\mathrm{R}_{\mathrm{c}}=$ Circularity ratio, $\mathrm{A}=$ Watershed area, $\mathrm{P}=$ Perimeter of watershed.

\subsubsection{Elongation ratio}

Elongation ratio is the ratio between the diameter of the circle having the same area as the watershed and maximum length of the basin (Schumn, 1956).

Smaller form factor shows more elongation of the basin. The watershed with higher form factor will have higher peak 
flow for shorter duration. Whereas elongated watershed with low form factor, will have a flatter peak of flow for longer duration.

$$
R_{e}=\frac{2 \sqrt{\frac{A}{\pi}}}{L}
$$

Where $\mathrm{R}_{\mathrm{e}}$ is the Elongation ratio, $L$ is the total length of watershed and $A$ is the total area of watershed.

The value of elongation ratio ranges from 0.4 to 1 , lesser the value, more is the elongation of the watershed. For the present study area elongation ratio is calculated as 0.645 .

\subsubsection{Drainage density}

Drainage density is the other element of drainage analysis which provides a better quantitative expression to the dissection and analysis of land forms, although a function of climate, lithology, structures and relief history of the region, etc. can ultimately be used as an indirect indicator to explain those variables, as well as the morphogenesis of landform.

Drainage density $\left(D_{d}\right)$ is one of the important indications of the linear scale of landform elements in stream eroded topography. It is defined as the total stream length of all stream order to the total area of watershed. The drainage density, which is expressed as $\mathrm{km} / \mathrm{Sq} . \mathrm{km}$, indicates a quantitative measure of the average length of stream channel area of the watershed. Drainage density varies inversely with the length of the overland flow, and therefore, provides at least some indication of the drainage efficiency of the basin. Drainage density is mathematically expressed as:

$$
D_{d}=\frac{\sum_{i=1}^{N} L_{u}}{A}
$$

Where $\sum_{i=1}^{N} L_{u}=$ Cumulative length of all streams $(\mathrm{km})$

$$
\mathrm{A}=\text { Area of watershed (Sq. km) }
$$

The measurement of drainage density provides a hydrologist or geomorphologist with a useful numerical measure of landscape dissection and runoff potential. On a highly permeable landscape, with small potential for runoff, drainage densities are sometimes less than 1 kilometer per square kilometer. On highly dissected surfaces densities of over 500 kilometers per square kilometer are often reported. Closer investigations of the processes responsible for drainage density variation have discovered that a number of factors collectively influence stream density. These factors include climate, topography, soil infiltration capacity, vegetation, and geology. The low value of drainage density influences greater infiltration and hence the wells in this region will have good water potential leading to higher specific capacity of wells. In the areas of higher drainage density the infiltration is less and surface runoff is more. The drainage density can also indirectly indicated groundwater potential of an area, due to its surface runoff and permeability. The value obtained (drainage density) was $1.697 \mathrm{Km} / \mathrm{Sq} . \mathrm{km}$ for the present study. From this, it was inferred that the area is very coarser watershed. The drainage density obtained for the study area is low indicating that the area has highly resistant or highly permeable sub-soil material.

\subsubsection{Constant of channel maintenance}

The inverse of drainage density is the constant of channel maintenance (C). It indicates the number of Sq.km of watershed required to sustain one linear $\mathrm{Km}$ of channel.

$$
\mathrm{C}=\frac{1}{\mathrm{D}_{\mathrm{d}}}
$$

It not only depends on rock type permeability, climatic regime, vegetation, relief but also as the duration of erosion and climatic history. The constant of channel maintenance is extremely low in areas of close dissection.

\subsubsection{Stream frequency}

Stream frequency may be expressed by relating the number of stream segments to the area drained. In other words, Stream frequency is the total number of stream segments in a watershed divided by the area of the watershed. Horton, 1932) introduced stream frequency or channel frequency as number of stream segments per unit area. For the present study, the stream frequency is 1.67 .

$$
S_{f}=\frac{\sum_{i=1}^{N} N_{u}}{A}
$$

Where $\sum_{i=1}^{N} N_{u}=$ Total no. of stream segments $\mathrm{A}=$ Total area of watershed (Sq. $\mathrm{km})$. 


\subsection{Relief aspects}

Relief aspects are an important factor in understanding the extent of denudational process undergone within the catchment and it is indicator of flow direction of water.

\subsubsection{Watershed relief}

Watershed relief is the difference in elevation between the remotest point in the water divide line and the discharge point of the watershed.

$\mathrm{H}=$ (Difference in elevation of the highest point of watershed) - (Difference in elevation of the watershed outlet)

The difference in elevation between the remotest point and discharge point is obtained from the available contour map. The highest relief is formed in watershed at an elevation of $930.250 \mathrm{~m}$ above mean sea level. The lowest relief was obtained at the Byramangala Reservoir at an elevation of $696.470 \mathrm{~m}$ above msl. The overall relief calculated for the watershed was $0.234 \mathrm{~km}$.

\subsubsection{Relief ratio}

Schumm (1956) defined relief ratio as the total watershed relief to the maximum length of the watershed. The relief ratio for the watershed was obtained as 0.0068 . The relief ratio increases overall the sharpness of the drainage basin and it is an indicator of intensity process operating as the shape of the watershed.

$$
\mathrm{R}_{\mathrm{h}}=\frac{\mathrm{H}}{\mathrm{L}}
$$

Where $\mathrm{R}_{\mathrm{h}}=$ Relief ratio

Where $\mathrm{H}=$ Total catchment relief $(\mathrm{km})$

$\mathrm{L}=$ Maximum length of catchment $(\mathrm{km})$

\subsubsection{Relative relief}

Relative relief is defined as the ratio of the maximum watershed relief to the perimeter of the watershed. It is computed as 0.0054 using the equation

$$
\mathrm{R}_{\mathrm{r}}=\frac{\mathrm{H}}{\mathrm{P}}
$$

Where $\mathrm{R}_{\mathrm{r}}=$ Relative relief; $\mathrm{H}=$ Maximum relief $(\mathrm{km}) ; \mathrm{P}=$ Perimeter $(\mathrm{km})$

\subsubsection{Ruggedness number}

Strahler (1964) defined Ruggedness number is the product of the watershed relief and drainage density and usually combines slope steepness with its length. High values of the ruggedness number in the watershed area because both the variables like relief and drainage density are enlarged. It is computed as 0.397 using the equation.

$$
R_{n}=H D_{d}
$$

Where $\mathrm{R}_{\mathrm{n}}=$ Ruggedness number, $\mathrm{H}=$ Watershed relief $(\mathrm{km}), \mathrm{D}_{\mathrm{d}}=$ Drainage density $\mathrm{km} / \mathrm{Km}^{2}$

Table 6 shows different morphometric parameters of Vrishabhavathi watershed.

Table -2: Different Morphometric Parameters of Vrishabhavathi Watershed

\begin{tabular}{|l|l|l|}
\hline Watershed Parameters & Units & Values \\
\hline Watershed Area & Sq.km & 381.465 \\
\hline Perimeter of the Watershed & $\mathrm{km}$ & 98.628 \\
\hline Highest Stream Order & No. & 6 \\
\hline Length of watershed & $\mathrm{km}$ & 34.150 \\
\hline Maximum width of Watershed & $\mathrm{km}$ & 20.373 \\
\hline Cumulative Stream Segment & $\mathrm{km}$ & 815 \\
\hline Cumulative Stream Length & $\mathrm{km}$ & 647.573 \\
\hline Length of overland flow & $\mathrm{km}$ & 0.295 \\
\hline Drainage Density & $\mathrm{Km} / \mathrm{Sq} \cdot \mathrm{km}$ & 1.697 \\
\hline $\begin{array}{l}\text { Constant of Channel } \\
\text { Maintenance }\end{array}$ & $\mathrm{Sq} \cdot \mathrm{km} / \mathrm{Km}$ & 0.589 \\
\hline Stream Frequency & & \\
\hline Bifurcation Ratio & $\mathrm{No} / \mathrm{Sq} \cdot \mathrm{km}$ & 2.136 \\
\hline Length Ratio & & 3.84 \\
\hline Form Factor & & 1.931 \\
\hline Circularity Ratio & & 0.327 \\
\hline Elongation Ratio & & 0.492 \\
\hline Total Watershed Relief & $\mathrm{km}$ & 0.645 \\
\hline Relief Ratio & & 0.234 \\
\hline Relative Relief & & 0.0068 \\
\hline Ruggedness Number & & 0.0054 \\
\hline
\end{tabular}

\section{CONCLUSION}

From the quantitative study, it is seen that the basin forms the dendritic pattern of drainage. Average bifurcation ratio is calculated for the watershed as 3.84. The value of $\mathrm{Rb}$ in the present case indicates that watershed has suffered less structural disturbance and the watershed may be regarded as the elongated one. Drainage density reflects land use and affects the infiltration and the watershed response time between the precipitation and discharge. For the present study the drainage density is evaluated to be 1.697 $\mathrm{Km} / \mathrm{Sq} . \mathrm{km}$ which indicates that the area is of coarser in nature. 
The circularity ratio for the watershed is 0.492 , which indicates mature nature of topography. Its low, medium and high values area correlated with youth, mature and old stage of cycle of tributary watershed of the region. The elongation ratio is 0.645 , which indicates that the watershed is elongated. The stream frequency obtained for the study area is $2.136 \mathrm{No} . / \mathrm{Sq} . \mathrm{km}$. So it is classified under the class of low drainage density, leading to higher bifurcation ratio in to the soil. On the whole, the watershed has a total relief of 0.234 $\mathrm{Km}$. The relief aspect shows that the watershed has enough slope for runoff to occur from the source to the mouth of watershed. The morphometric analysis results in dimensionless parameters for the watershed. This helps to compare the watershed with the neighbouring watersheds and to make decision for constructing hydraulic structures to combat erosion.

\section{REFERENCES:}

1.Balakrishna H B (2008). Spatial decision support system for watershed management using Remote Sensing and Geographic Information System, Ph.D. Thesis, UVCE, Department of Civil Engineering, Bangalore University.

2.Clarke J J (1966), Morphometry from map, Essays in geomorphology. Elsevier Publishing Company, New York p 235-274.

3.Horton R E (1945) Erosional development of streams and their drainage basins: Quantitative Morphology, Bull Geological Society of America 56:275 361 .

4.Lillesand Thomas, Kifer M, Ralph W, (2002) Remote Sensing and Image Interpretation, 4th Ed., John Wiley \& Sons, Inc. New York.

5.Magesh N S, Jitheshlal K V and Chandrasekar N(2013) Geographical information system-based morphometric analysis of Bharathapuzha river basin, Kerala, India. Appl Water Sci (2013) 3:467-477.

6.Sangita Mishra.S, Nagarajan.R (2010) Morphometric analysis and prioritization of subwatersheds using GIS and Remote Sensing techniques: a case study of Odisha, India. International journal of geomatics and geosciences Volume 1, No 3, 2010.

7.Schumm S. A., (1956) Evolution of Drainage Systems and Slopes in Bad Lands at Perth, Amboy, New Jersey, Bull. Geol. Soc. Amec., 67, pp. 597-646.

8.Shakil Ahmad et al (2012) Geoinformatics for assessing the morphometric control on hydrological response at watershed scale in the Upper Indus Basin. J. Earth Syst. Sci. 121, No. 3, June 2012, pp. 659-686

9.Strahler A N (1964) Quantitative Geomorphology of Drainage Basin and Channel Networks. Handbook of
Hydrology (edited by Ven Te Chow) Mc Graw Hill,Section 4-11.

10.Subramanya, K., (2012) A Text Book of Engineering Hydrology, Tata McGraw-Hill Publications, New Delhi.

11.Vandana M (2013) Morphometric analysis and watershed prioritization. A case study of Kabini River Basin, Wayanad District, Kerala, India. Indian Journal of Geo Marine Sciences. Vol 42(2), April 2013, pp 211- 222.

12.Ven Te Chow (1964), Handbook of applied Hydrology, McGraw-Hill Book Company.

\section{BIOGRAPHIES:}

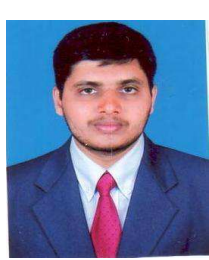

\section{ARA VINDA P T}

Assistant Professor, Department of Civil Engg, Govt Engg College Ramanagara, Karnataka, India

Main research areas: Watershed management, remote sensing and GIS. Email: aravindapt@gmail.com

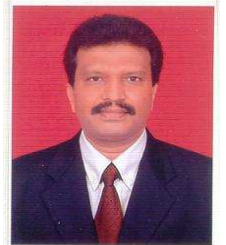

\section{Dr.H B BALAKRISHNA}

Professor, Department of Civil Engg, Bangalore Institute of Technology, Karnataka, India, Main research areas: Watershed management, remote sensing and GIS. Email: balubit@gmail.com 